\section{CURRENT} WORLD

ENVIRONMENT
ISSN: 0973-4929, Vol. 16, No. (2) 2021, Pg. 348-361

\section{Current World Environment}

www.cwejournal.org

\title{
Impact of Industrial Waste on Natural Resources: A Review in the Context of Bangladesh
}

\author{
UMAMA BEGUM RUBA*, KAKON CHAKMA, \\ JARRINYEASMIN SENTHI and SAIDUR RAHMAN
}

Faculty of Agriculture, Sylhet Agricultural University, Sylhet, Bangladesh.

Abstract

Although the industrial sector contributes significantly to Bangladesh's economic growth and development, unplanned rapid industrialization is having a detrimental impact on natural resources. Since industrial waste has become a major concern, this study reviewed previously published research papers to highlight the detrimental effects of industrial waste on natural resources. This review observed industrial waste have a substantial impact on natural resources, causing contamination of the air, water, and soil, alongside disruption of aquatic and forest ecology. Therefore, effective policy enforcement is expected to ensure that industrialization is sustainable, both in terms of mitigating environmental pollution and promoting more environmentally friendly industries. Bangladesh's long-term sustainability and prosperity necessitate industrialization, but it should be done in an environmentally sustainable manner.

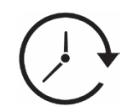

Article History

Received: 08 May 2021

Accepted: 25 August 2021

\section{Keywords}

Air;

Bangladesh;

Heavy Metal;

Industrial Waste;

Industrial Pollution;

Soil;

Water.

\begin{tabular}{llll}
\multicolumn{2}{l}{ Acronym/Abbreviation } & TLV & Threshold Limit Value \\
EIA & Environmental Impact Assessment & EPA & Environmental Protection Agency \\
EIV & Environmental Impact Value & DoE & Department of Environment \\
NAAQS & National Ambient Air Quality & SPM & Suspended Particulate Matter \\
& Standards & TDS & Total Dissolved Solids \\
\multirow{2}{*}{ USNAAQS } & United States National Ambient Air & TSS & Total Suspended Solids \\
& Quality Standards & DO & Dissolved Oxygen \\
BSTI & Bangladesh Standards and & EC & Electrical Conductivity \\
& Testing Institution & EQS & Environmental Quality Standard \\
\multirow{2}{*}{ US EPA } & United States Environmental & COD & Chemical Oxygen Demand \\
& Protection Agency & BOD & Biochemical Oxygen Demand \\
WHO & World Health Organization & LCA & Life Cycle Assessment
\end{tabular}

CONTACT Umama Begum Ruba umamaruba909@gmail.com 9 Faculty of Agriculture, Sylhet Agricultural University, Sylhet, Bangladesh.

\section{(c) (i)}

(c) 2021 The Author(s). Published by Enviro Research Publishers.

This is an Open Access article licensed under a Creative Commons license: Attribution 4.0 International (CC-BY).

Doi: http://dx.doi.org/10.12944/CWE.16.2.03 
ETP

DEPZ

TR

EDI

ERI

\section{Introduction}

Bangladesh is a mainly agrarian nation, with people relying on agriculture for food, fuel, fiber, raw materials, and other necessities. Bangladesh's favorable climatic conditions and abundance of natural resources have made this sector a promising source for employment, poverty reduction, and food security. Along with Agriculture, Bangladesh

$\begin{array}{ll}\text { PLI } & \text { Pollution Load Index } \\ \mathrm{PM}_{2.5} & \text { Particulate with a diameter of } 2.5 \\ & \text { microns or less } \\ \mathrm{PM}_{10} & \begin{array}{l}\text { Particulate with a diameter of } 10 \\ \text { microns or less }\end{array}\end{array}$

has prioritized the industrial and service sectors to accelerate economic growth. Bangladesh's favorable policies and cheap labor attracted foreign investment in industry sector. As an output, the economy is expanding very fast, and rapid industrialization is taking place. (Figure 1) shows that industries have expanded all over the country.

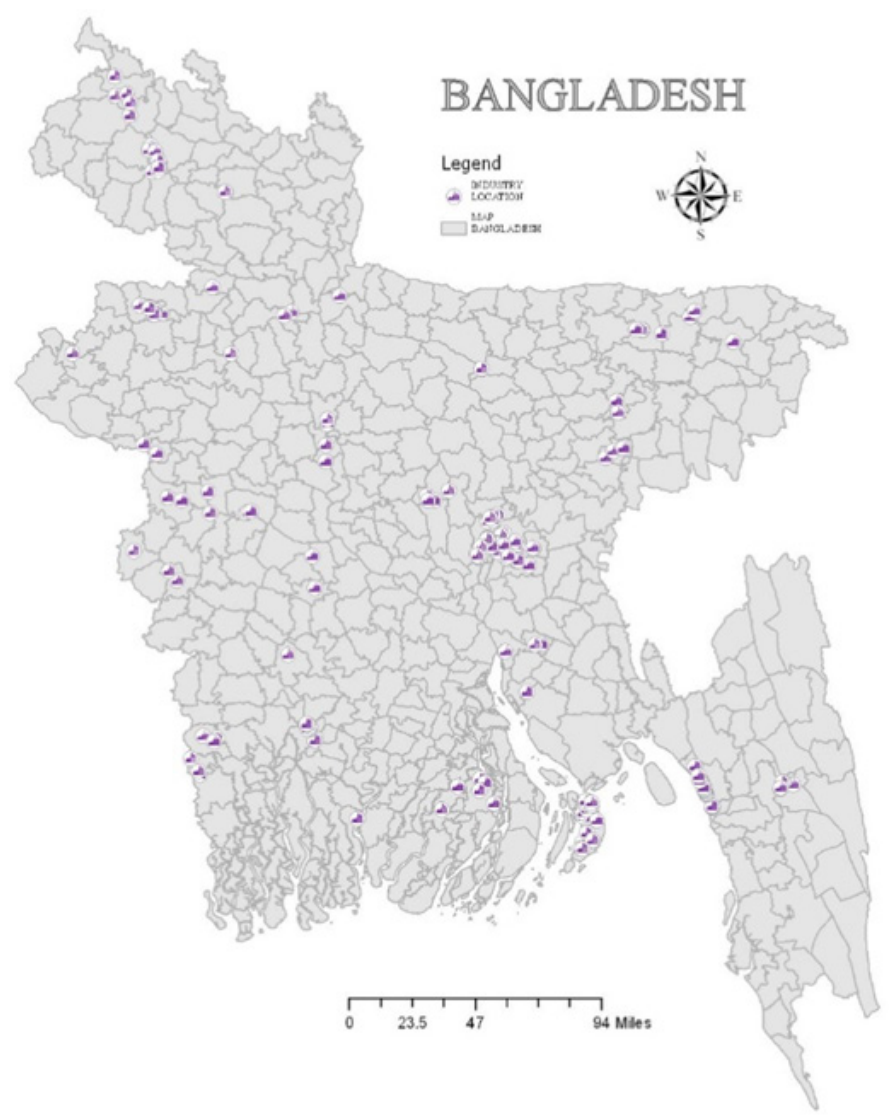

Fig. 1: Location of industries in Bangladesh ${ }^{1}$

Bangladesh is now one of the world's fastest developing economies, including one of the top five exporters of Ready Made Garments (RMG), textiles, and apparel sector, accounting for roughly $20 \%$ of total GDP. ${ }^{2}$ In 2019, the Industry sector contributed to total GDP around $31.13 \% .2$ Manufacturing sector is the major contributor to the GDP of Bangladesh (Figure 2). Bangladesh Economic growth improves as the industry sector employs a larger share of employment, providing for almost $21.32 \%$ of overall employment in 2019. ${ }^{3}$ 


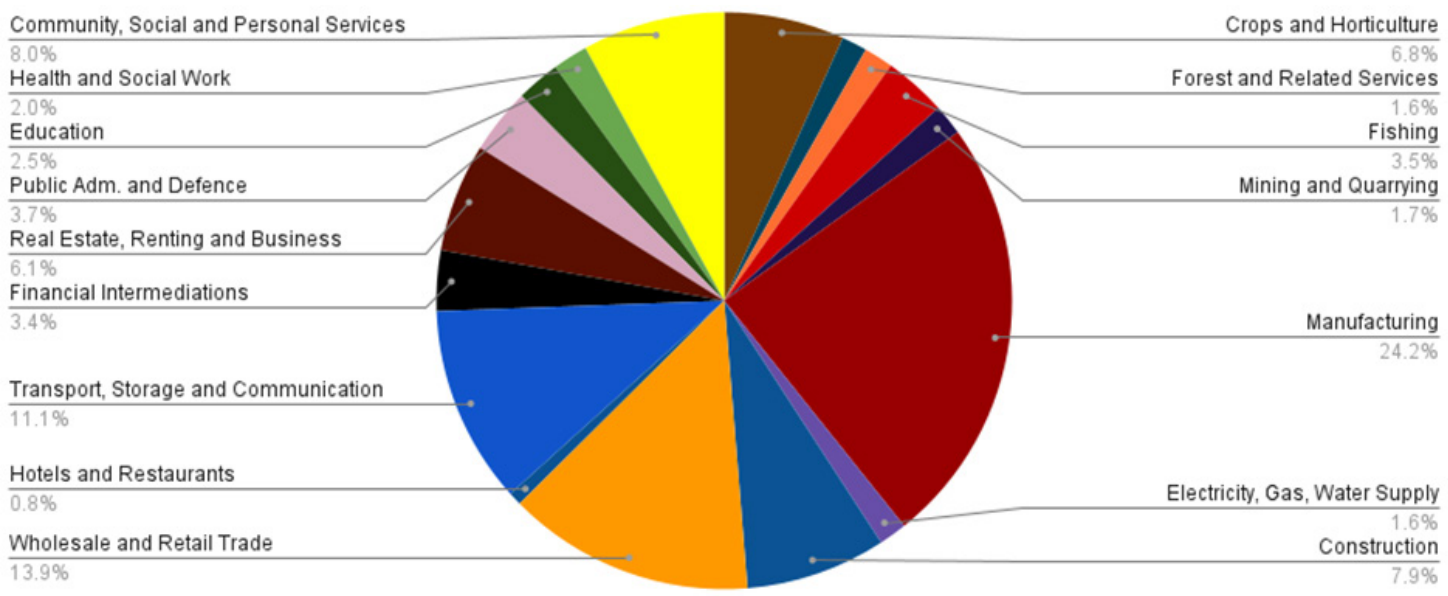

Fig. 2: Sectoral contribution to GDP ${ }^{4}$

Though industrial sector has a huge contribution to economic development but unplanned rapid industrialization is bringing out adverse impacts on natural resources.Bangladesh loses 8000 ha. of farmland annually due to rapid urbanization, industrialization, unanticipated rural housing, and infrastructure development. ${ }^{5}$ Industrialization is one of the main reasons for environmental pollution ${ }^{6}$ and industrial pollution is wreaking havoc on the environment, destroying natural resources. Natural and anthropogenic practices are increasingly depleting resources, which is alarming. Agriculture, fisheries and forestry contributed $30.49 \%$ of GDP in 1990, but that share has dropped to $12.68 \%$ in 2019. 7 According to World Bank, "Forest area remained $30.72 \%$ of land area in 2016 and agricultural land stood at $36.9 \%$ of land area in $2018, \mathrm{CO}_{2}$ emission determined 4.56 metric tons per capita in 2016". Every year, Bangladesh loses over $\$ 6.5$ billion, around $3.4 \%$ of its GDP, due to environmental contamination and depletion in urban environments, with pollution accounting for $28 \%$ of all deaths, which is $16 \%$ of the global average. ${ }^{8}$ Bangladesh spotted $1^{\text {st }}$ position among most polluted countries with a PM2.5 reading of 83.30 micrograms per cubic meter and Dhaka ranked $21^{\text {st }}$ position among most polluted cities in 2019. ${ }^{9}$

Various industries are constantly increasing with planned or unplanned manner and adding pollutant concentration in the atmosphere. Chemicals emitted by various industries are listed in (Table 1). Untreated waste from tannery industries wreaks havoc on fisheries, forests, and wildlife. ${ }^{10}$ The tannery and leather industries released the most dangerous substances into water, whereas the pulp and paper industries were also reported to be responsible for water pollution. Industrial pollution created challenges for fisheries sector by the pollution of water and marine lives in the coastal region are endangered. ${ }^{11}$ Pollution of air, water, land caused mainly by pulp and paper, food, tannery and leather industry where food industry caused greater air pollution, and sugar, mill, oil factories contributed in pollutant emission in the air. ${ }^{12}$ Hence, $81 \%$ of hazardous chemical emissions would end up in the air. ${ }^{12}$ Artificial dyes like sulfur, azoic, indigoids, nitrates, acetic acid, enzymes, and soap containing heavy metalloids and compounds posed a significant danger to the natural environment and living organisms.$^{13}$ Ecosystem and public health were found in threat due to heavy metals discharge..$^{14}$ The exposure of hazardous metals hinted at the influential detrimental effect on the ecosystem, human health, aquatic ecotoxicity, and terrestrial ecotoxicity where $\mathrm{Cr}$ was found as a major soil contaminant and $\mathrm{Pb}, \mathrm{Zn}$ possessed potentialities for groundwater contamination. ${ }^{15}$

In 2008, Asian Development Bank reported an inventory of Hazardous waste in Bangladesh. ${ }^{16}$ Every year, the textile dyeing industry generates around 113.72 tons of solid waste and 99.75 million cubic meters of liquid waste.Yearly, the tanning industry yearly generates around 26,250 tons of solid waste and 1.3 million cubic meters of liquid waste. Hospitals and clinics generate 12,271 tons of solid waste. Agriculture-related industries, such as 
pesticide manufacturing, produce 277 tons of solid waste and 7.8 million cubic meters of liquid waste per year, while fertilizer manufacturing generates 357 tons of solid waste and 10.97 million cubic meters of liquid waste per year. Oil refining generates 4 tons of solid trash per year and 0.61 million cubic meters of liquid waste per year.

Table 1: Chemicals regarding various industries ${ }^{16}$

\begin{tabular}{ll}
\hline Industry & \multicolumn{1}{c}{ Chemicals } \\
\hline Acid Handlers and Suppliers & Nitric acid, Sulfuric acid, Hydrochloric acid \\
Adhesive and Glue Makers & Methylethyl, Ketones, Toluene, Acetone \\
Bleaching Powder & Chlorine \\
Battery Manufacturer & Lead, Sulfuric acid \\
Chlor Alkali (Caustic Soda) & Chlorine, Mercury, Hydrogen gas \\
Fertilizer & Ammonia, Carbon monoxide, Phosphoric acid, Sulfuric acid \\
Paints and Varnishes & Solvents, Metallic oxides of Pb, Ti \\
Pesticides & Benzene, Toluene, Butane, Organophosphorus materials \\
Pharmaceutical & Organic chemicals \\
Industrial Chemicals & Sulfuric acid, Sodium Silicate \\
Plastics & PVC Solvents \\
Rayon Manufacture & Mercury, Chlorine \\
Synthetic Foam & Cyanides, Solvents \\
Vegetable oils, Ghee & Hydrogen, Toxic Dyes, Hazardous Waste \\
Textile, Dying and printing & \\
Clinic and Hospitals & \\
Ship breaking and Dismantling & \\
Petroleum Refinery & \\
E-waste & \\
Paper and Pulp & \\
\hline
\end{tabular}

The tannery industry's EIA report revealed a detrimental impact on physical and biological resources such as air quality, surface water quality, land quality, fisheries, aquatic biology, vegetative cover, biodiversity, and agriculture, concluding that soil and river water ambiance is impaired, as well as a disrupted ecological equilibrium. ${ }^{17}$ Total EIV obtained negative along with adverse impact on physical resources (air, water, and soil) and ecological resources (fisheries, forestry). ${ }^{18}$ Physical and ecological resources were found adversely affected as their EIV obtained negative due to washing and dyeing industries. ${ }^{19}$ The EIA report of ship-breaking industries found a negative effect on abiotic and biotic factors which included soil quality, soil fertility, air quality, water quality, vegetation coverage, animal life, forest, and biodiversity. ${ }^{20}$ Limitation of resources, absence of interagency coordination, lack of monitored regulation determined as constraints of administration, resulting in continued pollution. ${ }^{21}$
Since industrial disposal has become a matter of concern, this study brings together previously published papers to highlight detrimental effect of industrial waste on natural resources. The purpose of this study is to discuss how industrial wastes are affecting physical and ecological resources of Bangladesh. This study contributes to the existing literature by analyzing the findings of numerous evidence on the effects of industrial waste on air, water, soil, aquatic, and forest resources. This may help the policymakers to take adequate measures to protect natural resources by minimizing industrial pollution.

\section{Impact on Physical Resources \\ Pollution of Air}

In Bangladesh, Industrial exposures were identified as major causes of air pollution. ${ }^{22,23}$ The brick kiln industry, cement, steel, rice mill, glass factory regarded as major influential contributors in 
air quality deterioration. ${ }^{24}$ Also, agro-based industries like paper, pulp, sugar, textile, tanneries, pharmaceuticals, oil refineries, fertilizers, and chemical factories were found responsible for the vulnerable quality of air. ${ }^{25}$ Industries were marked as major pollution sources ${ }^{26}$ and air contamination was exacerbated by factory residuals, smoke emissions, and poor solid waste disposal. ${ }^{25}$ EIA report of tanneries in Dhaka revealed negative effects on air quality ${ }^{17}$ that leads to air pollution. ${ }^{10}$ EIA report of textile dyeing factories in Gazipur revealed the detrimental impact on air meteorology and air quality. ${ }^{19,27}$ Even at sugar mill localities, $\mathrm{PM}_{10}$, $\mathrm{NO}_{x}$, and $\mathrm{SO}_{2}$ were noticed. ${ }^{28}$ In Kushtia sugar mills, Particulate Matter (PM10) found high concentration contributor, and API hinted health issues due to intensive air pollution. ${ }^{28} \mathrm{~A}$ study conducted in greater Dhaka city found, $\mathrm{PM}_{2.5}, \mathrm{PM}_{10}, \mathrm{SO}_{2}, \mathrm{NO}_{2}$, and $\mathrm{CO}$ maximum during winter and minimum in monsoon. ${ }^{26}$ Particulate Matter concentration showed major threat to existing habitants as they surpassed level of Bangladesh NAAQS and USNAAQS standards. ${ }^{26}$ In dry season, the brick kiln has been regarded as a critical contributor to air pollution in Dhaka. ${ }^{29}$ Brickfields Particulate Matter was identified as a significant pollutant in Savar, raising concerns in the surrounding areas of the brickfield..$^{30}$ The brick kiln was discovered to be the primary source of sulfur dioxide, carbon monoxide, hydrocarbon pollutants, ${ }^{30}$ and black carbon particle composition. ${ }^{23}$ Exposures of Sulfur dioxide, Carbon dioxide, black carbon, and Carbon monoxide concentration found raising at an alarming rate due to brick kiln clusters. ${ }^{31}$ The waste of garment factories responsible for odor problems. ${ }^{32}$ Petroleum refineries emit harmful and toxic air pollutants such benzene, xylene, toluene, and ethylbenzene. ${ }^{33}$ The value of SPM crossed the TLV consulted by WHO, EPA, and DoE. ${ }^{34}$ To control air emissions, plans and measures should be established that is essential to include government regulations and action plan. ${ }^{29}$ Industrial policies such as a comprehensive land use strategy, cluster management, technological and emission standard strategies, maintenance and management, appropriate plant for air pollution mitigation, and regulating importation for coal quality control must all be implemented. ${ }^{24}$ Industries like tannery, battery, pharmaceutical, tobacco should be relocated with proper disposal system of discharges ${ }^{22}$ and for textile factories, air quality index were suggested. ${ }^{19,27}$ ETP installation, legislation enforcement regarding environment, waste management, training program for workers, relocation of industries out of city determined as requisites. ${ }^{32}$

\section{Pollution of Water}

In Bangladesh, Industrial discharges are one of the major sources of water pollution. ${ }^{35}$ Around $90 \%$ of water is utilized by energy sectors and humans whereas divergence of water from underground and surface water sources is higher by the industries compared to their real amount of consumption. ${ }^{36}$ Surface water has been heavily polluted as a result of the rise in industries. ${ }^{37}$ In Bangladesh, Heavy metal translocation increased the concentration in agricultural irrigation water of industrial zone. ${ }^{38,39}$ Increased in concentration of $\mathrm{EC}, \mathrm{Cd}, \mathrm{Pb}$, and $\mathrm{Ni}$ become a significant threat. ${ }^{6,37}$ Research conducted in Tongi canal found, irrigation water became problematic as concentration of $\mathrm{HCO}_{3}, \mathrm{SO}_{4}, \mathrm{PO}_{4}$, $\mathrm{K}$ contents surpassed the recommended limit. ${ }^{6}$ In Narai canal and Balu river, TDS, DO, and $\mathrm{NH}^{4+}$ were in extreme condition and which indicated that water became unsuitable for human, aquaculture, and irrigation practices. ${ }^{40}$ The estimated EC showed medium to high salinity due to heavy metalloids in the Karatoa river water sources, while the measured DO indicated stressed aquatic life, and water bodies were unsuitable and hard graded. ${ }^{41}$ Heavy metals like arsenic, which is rising at an unexpected pace in underground water due to elevated amounts of $\mathrm{Fe}, \mathrm{Cr}, \mathrm{Pb}$, and $\mathrm{Ni}$ are present in contaminated water sources. ${ }^{42}$ Tannery industries have raised concerns over environmental sustainability after it was discovered that they have a detrimental impact on the atmoshphere. ${ }^{10}$ Mismanagement of waste from tanning plants, inferior technology, and insufficient disposal systems exacerbated quality of the water, leading to disrupted aquatic biology and surface water contamination, higher levels of $\mathrm{S}^{2-}, \mathrm{Fe}, \mathrm{NH}_{3}, \mathrm{COD}$, and $\mathrm{EC}$ indicate real problem because they pose a significant danger to the ecosystem and also overall pollution. ${ }^{43} \mathrm{~A}$ study conducted in Madina tannery of Chittagong found EIV was negative regarding physiochemical factors like groundwater pollution, surface water contamination. ${ }^{10}$ Tannery effluents had a lower $\mathrm{pH}$ and $\mathrm{DO}$ but a high amount of $\mathrm{BOD}, \mathrm{Cl}^{-}, \mathrm{SO}_{4}$, and $\mathrm{Cr}^{44}$ Textile dyeing has a detrimental impact on quality of surface water. ${ }^{19,45}$ Textile dyeing effluents contained higher $\mathrm{pH}, \mathrm{NO}_{2}{ }^{-}$and $\mathrm{NO}_{3}^{-44}$ and untreated textile discharges decreased the amount of DO, 
depleted groundwater level with its contamination, adversely affected aquatic ecology and also led to climate change. ${ }^{46}$ Waterbodies became badly polluted in Bangladesh because petroleum and petrochemical industries expanded near freshwater sources. ${ }^{33}$ EIA report revealed influential detrimental impact of textile and dyeing industries waste on water. ${ }^{19}$ Physio-ecological and ecological resources were found disturbed. ${ }^{19,45}$ Most adverse impact found on state of surface water ${ }^{45}$ while influential impact on surface water, groundwater, hydrology, aquatic biology, and fisheries. ${ }^{19,45}$ In Dhaka, Textile and tanning industry wastes had higher EC, TSS, TDS, and heavy metal levels. ${ }^{44}$ Study conducted in 5 rivers of Bangladesh (Buriganga, Turag, Shitalakkha, Dhaleshawari, Brahmaputra) found that, quality of Surface water disrupted due to waste of textile factories as COD, BOD, SS, alkalinity, $\mathrm{Cl}$, DO, TDS, EC were beyond EQS standard and thus it is hazardous to ecosystem and human body. ${ }^{47}$ Printing and Dyeing factories require high volume of water for production purposes and conventional wastewater treatment plants caused water pollution by turning it to waste water. ${ }^{13}$ Pharmaceutical waste has affected aquatic life, microorganisms, and human body. ${ }^{48}$ EC, TDS, chloride, metal and oil contents found higher in Sitakundo due to increased level of contamination in recycling and ship breaking industries of Bangladesh that EIV was not acceptable for sustainable environment. ${ }^{18}$ Significant issues arose due to industrial pollutants, including high pollution, low fertility, high infestation, dermal disease, and low yield. ${ }^{37}$ Toxic metals are responsible for deterioration of source of agricultural irrigation water and thus enter to the food chain. ${ }^{41}$ Effective management of dumping site,${ }^{40}$ maintaining distance from water source,,$^{40}$ installation of ETP, ${ }^{40}$ rules and legislation by industry in case of disposal into the river, ${ }^{40}$ appropriate water treatment, ${ }^{41}$ The DoE should ensure that sources of pollution are monitored, that effective initiatives are approved, and that environmental law is applied. ${ }^{6}$ To decrease water pollution proper monitoring, modern treatment procedures, modern water supply management, consciousness regarding safe water utilization and implementation of laws must be focused. ${ }^{42}$ In case of tannery industries, relocation of tannery industry out of city ${ }^{17}$ or particular industrial zone, ${ }^{10}$ construction of central sewage treatment plant ${ }^{17}$ or waste treatment, ${ }^{10}$ proper environmental management plan, ${ }^{10,17}$ ensuring safety to workers, ${ }^{17,18}$ minimizing intensity of other pollution and hazards are pre requisite. ${ }^{17}$ For dying and printing industries waste treatment and legislation should be established. ${ }^{13}$ For ship breaking and recycling industries specific zones for ship processing, appropriate disposal of wastes, national polices, scientific research techniques, Safety for human and aquatic lives should be assured..$^{18}$ To protect aquatic biology and minimizing water depletion and stress, discharge volume of wastes it is required to take several initiatives for textile industries. ${ }^{46}$ Appropriate technologies ${ }^{46}$ cleaner production, ${ }^{46}$ recycling of used water, ${ }^{46}$ ETP installation, ${ }^{45,19}$ designed project plan for protecting fisheries, ${ }^{45}$ worker's safety, ${ }^{19,45}$ training, ${ }^{45}$ waste disposal and effluents treatment ${ }^{19}$ should be ensured.

\section{Pollution of Soil}

Factories are a significant contributor to the diversion of agricultural land as well as the decline in agricultural production, ${ }^{49}$ The natural environment's equilibrium was broken after the growth of industries. ${ }^{50}$ Food insecurity has been linked to industrialization as a factor restricting agricultural productivity. ${ }^{51}$ Industrial development has outpaced agricultural growth, ${ }^{51}$ and it generates heavy metalloids ${ }^{52,53}$ and solid waste, ${ }^{54}$ and environmental deterioration. ${ }^{55}$ Heavy metals released into the soil by factories pose a significant danger to the atmosphere, as soil toxicity and pollution result from rapid industrial activity.56Heavy metal deposition in farm soils is closely related to industrial wastewater used for irrigation. ${ }^{57}$ Although the readymade garments industry contributed significantly to growth of nearby areas, the inadequate amenities and facilities exacerbated the problem. ${ }^{50}$ The ascendant order of metallic concentration $(\mathrm{Fe}>\mathrm{Zn}>\mathrm{Ni}>\mathrm{Cr}>\mathrm{Pb}>\mathrm{Cu}$ $>\mathrm{Cd}$ ) was found in arable soil where $\mathrm{Cd}$ content in soil surpassed the allowable limit around industrial localities. ${ }^{39}$ Soil quality, concentration of heavy metalloids, and chemical attributes were marked to change as industrial effluents caused adverse impacts on downstream zone of waste unload site in Gazipur. ${ }^{58}$ Higher levels of sulfur, but lower levels of OM, N, and $\mathrm{P}$ as well as substantial amounts of $\mathrm{Zn}, \mathrm{Fe}, \mathrm{Cu}, \mathrm{Cd}$, and $\mathrm{Pb}$, were found in Gazipur's industrial sector. ${ }^{58}$ Located industrial sites were contaminated by heavy metalloids at a different level of parameter ${ }^{53}$ that polluted agricultural resources. ${ }^{52}$ In agricultural soil near DEPZ, great proportion of $\mathrm{As}, \mathrm{Fe}, \mathrm{Hg}, \mathrm{Mn}, \mathrm{Zn}$ was observed in the dry 
season and As, Fe, Mn, Zn, Hg determined in wet season. ${ }^{55}$ During dry season, significant amount of heavy metalloids were detected in the Tejgaon industrial areas, indicating that untreated residuals organic toxins and containing hazardous heavy metalloids were contaminating the ecosystem. ${ }^{59}$ An assessment study of soil quality near Barapukuria Coal Mining Industrial Zone revealed that, the production of iron pyrite and chalcopyrite during the coal mining process showed a negative effect on soil health, indicating a threat to the ecosystem and soil quality. ${ }^{60}$ The soil of Barapukuria Coal Mining Industrial Zone contained relatively lower $\mathrm{pH}$ and nitrogen levels than Standard Value whereas concentration of $\mathrm{K}$, Fe, OM, Cu exceeded the Standard Reference Value in terms of agriculture.60 $\mathrm{Cr}, \mathrm{Ni}, \mathrm{Pb} \mathrm{Cu}, \mathrm{Cd}$, and As were found in the nearness of industrial sites of Jhenaidah and kushtia districts, and the $\mathrm{Cd}$ content in agricultural soil surpassed the recommended level, indicating a moderate to very high Potential Ecological Risk. ${ }^{61}$ EDI value of $\mathrm{Pb}$, $\mathrm{Cr}$, As, $\mathrm{Ni} \mathrm{Cd}$, found higher, THQs values of $\mathrm{Pb}, \mathrm{Ni}$, As, $\mathrm{Cu}, \mathrm{Cd}$ surpassed the threshold value and TR of $\mathrm{As}, \mathrm{Pb}$ surpassed the US EPA threshold value in industrial localities of Tangail. ${ }^{62}$ Discharged wastes of multi industries (textile, dye, agrochemical, paint, and chemical) provided higher concentrations of $\mathrm{Zn}, \mathrm{Cu}, \mathrm{Cr}$, and $\mathrm{Pb}$ to the soil, irrigation water, and $\mathrm{As}, \mathrm{Cr}, \mathrm{Pb}$ concentration was measured beyond recommended limit. ${ }^{63}$ Geo-accumulation Index indicated, the presence of $\mathrm{Zn}$ and $\mathrm{Pb}$ degraded the soil moderately in Bhaluka industrial areas, with high levels of $\mathrm{Zn}, \mathrm{Cu}$, and $\mathrm{Pb}$ posing a hazard to surface soil quality and habitats. ${ }^{64}$ Study conducted in Dhaka Aricha road found $\mathrm{Cd}$ levels in soil were elevated, resulting in higher $\mathrm{Cd}, \mathrm{Cr}$ levels in vegetables also The Potential ERI showed that high concentration of Cd posed a danger to the surrounding environment, while the Transfer Factor of $\mathrm{Cd}, \mathrm{Pb}$ expressed the possibility of risk occurrence since they are higher accumulators in leafy vegetables. ${ }^{65} \mathrm{Cd}$, As, $\mathrm{Cu}$, $\mathrm{Pb}$, and $\mathrm{Ni}$ concentrations in 12 separate land use urban soils in Dhaka surpassed the Dutch Target Value, and $\mathrm{Cr}$ was found to be a contributory factor. ${ }^{66}$ Contamination Factor values indicated Cd contamination in urban soils due to metallic contamination, while the PLI revealed soil health deterioration. ${ }^{66}$ Uptake of heavy metalloids occurred by plants and enter to the food. ${ }^{58}$ EIA report of Hazaribag revealed, the tannery industry has a detrimental impact on ecology (vegetative cover, wildlife), and agriculture. ${ }^{67} \mathrm{~N}, \mathrm{P}, \mathrm{K}$ was observed to be lower on rice plants that were planted on contaminated soil, indicating a significant negative effect on soil and plant growth. ${ }^{37}$ Heavy metalloids are responsible for entering in ecosystem and deteriorate human health, wild and bio environment. ${ }^{55}$ Industrial Pollution is a core problem of environment as improper industrial practices exist for many decades. Solid waste management is constrained due to absent of recycling, appropriate handling, and disposing, awareness, financial support, and appropriate technologies. ${ }^{54}$ Careless waste unloading must be stopped, and waste handling with appropriate disposal policies must be ensured. ${ }^{58}$ More focus should be paid to the use of caustic soda and sulfuric acid during the production process, as well as the use of a pretreatment facility and product recycling. ${ }^{37}$ Rules and legislation, ETP installation, wastewater recycling, industrial modernization are prerequisites. ${ }^{55}$ Furthermore, there must be emphasized on solid waste disposal, effective plan, and evaluation of effects on soil quality should be executed. ${ }^{67}$ Industrial waste management should include monitoring carbon exposure, market-based reward governance, recycling, and green technology adaptation. ${ }^{25}$

\section{Impact on Ecological Resources Disruption of Aquatic Ecology}

Industrialization contributed significant Negative impact on aquatic animals because of heavy metals unloading.$^{68}$ One of the causes of worsening water quality, as well as negative impacts on sediments and aquatic fauna, has been described as industrialization. ${ }^{69}$ Aquatic pollution has been linked to industrialization ${ }^{70}$ where industrial discharges were found to be responsible for altering water chemistry ${ }^{71}$ and leading to wastewater accumulation in rivers. ${ }^{72}$ Owing to the lack of adequate treatment facilities, toxic wastes were identified ${ }^{72}$ as a source of pathogenic microbial contamination in the water sources of industrial localities, and the elevated rate of discharges signaled a serious threat to aquatic biology and ecosystems. ${ }^{70}$ Study conducted in Kushtia Sugar Mill areas found the metals of effluents failed to match the Standard of DoE and ground water quality. ${ }^{71}$ High values of TDS, BOD, $\mathrm{COD}, \mathrm{Cl}^{-} \mathrm{K}^{+}, \mathrm{Ca}^{+}, \mathrm{Mg}^{+}, \mathrm{SO}_{4}, \mathrm{PO}_{4}, \mathrm{NO}_{3}$, and low level of $\mathrm{DO}$ indicated water pollution and hinted toxicity to aquatic life. ${ }^{71}$ The water quality of Bhairab river nearside of Noapara Industrial area is at the lowest 
in the summer due to continous pollution, and high amount of $\mathrm{Fe}$ and $\mathrm{Mg}$ have an adverse impact on aquatic life. ${ }^{72}$ The dyes and chemicals of textile industries contained $\mathrm{Cu}, \mathrm{Cr}, \mathrm{Zn}$ and they were responsible for increased level of BOD and disruption of photosynthesis and re oxygenation that an impact on aquatic species. ${ }^{73}$ The raised concentrations of $\mathrm{Pb}, \mathrm{As}, \mathrm{Cr}$, Cd harm ecosystem of karnaphuli river. ${ }^{69}$ The studied water bodies of Buriganga river found affected as water quality that examined not suitable for aquatic ecosystem. ${ }^{35}$ Metals and chemicals from ship breaking industries had significant negative impact on marine ecosystem, fisheries. ${ }^{74}$ Marine ecology consisting fish, mammals, plants, planktons, reptile, benthic invertebrates faced physical inconvenience, and ecology was affected due to heavy metals discharge from ship breaking industrial activities in Shitakunda. ${ }^{75}$ Industrial toxic wastes have been listed as one of the sources of contamination in coastal region that could endanger aquatic species' survival. ${ }^{76}$ Toxic metals ( $\mathrm{Cu}, \mathrm{Cd}, \mathrm{Hg}$, $\mathrm{Cr}, \mathrm{Ni}, \mathrm{Pb}$, and $\mathrm{U}$ ) in water channels of coastal areas, which have an impact on water quality, aquatic biodiversity, and seafood safety. ${ }^{76}$ Industrialization influenced heavy metals toxicity in rupsa river which resulted in $\mathrm{As}, \mathrm{Pb}, \mathrm{Cd}, \mathrm{Cu}, \mathrm{Ni}, \mathrm{Cr}$ concentration at various ranges and calculated ERI expressed significant low level to moderate level of ecological risk. ${ }^{77}$ The high EC, color, and odor of Bangshi river indicated deteriorated water quality, water that was deemed unsuitable for aquatic biology, and industrial practices linked to this crisis, posing threat to aquatic assets' sustainability. ${ }^{78}$ Study performed in Bhaluka industrial area found $\mathrm{Zn}$ in wastewater which posed a hazard to aquaculture. ${ }^{79}$ At the adjacent lake of industrial zone in Savar, COD was observed to be out of the standard range, and $\mathrm{Cd}, \mathrm{Co}, \mathrm{Fe}, \mathrm{Pb}, \mathrm{Mn}$, and $\mathrm{Hg}$ were at above of the recommended level. ${ }^{80}$ Full Chrome Leather were identified to be a greater contributor in aquatic pollution such as aquatic eco toxicity and aquatic acidification whereas Chrome Retanned Crust Leather found significant contributor in aquatic eutrophication. ${ }^{8}$ The total and dissolved concentrations of $\mathrm{Ni}, \mathrm{Cr}, \mathrm{As}, \mathrm{Cu}, \mathrm{Cd}$, and $\mathrm{Pb}$ were detected in various ranges in Dhaka, indicating that unloaded wastewater from factories could degrade the aquatic ecosystem, and thus a wide variety of industries were remarked as a source of environmental pollution. ${ }^{82}$ Industrial effluents greatly increased the levels of metal content in estuarine water, resulting in a disrupted marine habitat. ${ }^{83}$ Concentrations of $\mathrm{As}, \mathrm{Zn}, \mathrm{Pb}, \mathrm{Cd}$, Ni, Cr, $\mathrm{Cu}$ in textile and tannery effluents were measured at various levels in Buriganga and Karnatoli river. ${ }^{84}$ Values of chloride, TDS, Total hardness, alkalinity of Rupsha river was out of BSTI limit where $\mathrm{Cr}, \mathrm{Pb}$, $\mathrm{Fe}, \mathrm{Ni}, \mathrm{Mn}, \mathrm{Ag}$ concentration exceeded the BSTI and $\mathrm{WHO}$ permissible limit as a result pollution of aquatic ecosystem lead to detrimental effects on the local environments. ${ }^{85}$ EIA report of tanneries of hazaribag expressed negative impact on fisheries, aquatic biology as unloading of solid wastes caused adverse impact on aquatic biology and fisheries. ${ }^{17}$ Tanneries wastewater directly fell into the river, resulting adverse effects to the aquatic biology, and TSS, TDS, TS were also higher which hinted negative impact86 that constraints photosynthesis of aquatic plants and planktons.86 The establishment of scrapping facilities by ship-breaking industries found to be responsible to collapse of fisheries stocks as most of them located near fisheries areas.87 Study conducted in khiru river found, Cd concentration of soil sediment and water exceeded the recommended limit and $\mathrm{Zn}, \mathrm{Cu}, \mathrm{Cd}, \mathrm{Pb}, \mathrm{Mn}$, $\mathrm{K}, \mathrm{Na}$, As were assessed in different fish muscle..$^{88}$ Concentration of $\mathrm{Fe}, \mathrm{Cr}, \mathrm{Pb}, \mathrm{Cd}$ found higher in water body of Balu river and $\mathrm{pH}, \mathrm{EC}$, appearance, color of water showed environmental risk. ${ }^{89}$ Mismanagement of garments wastes in Naranganj was found responsible for affecting environment of shitalakkhya river. ${ }^{32}$ Effluents of tannery, pulp, fertilizer industries caused adverse impact on aquatic life where water resources declination were highest among the socio-economic hazards. ${ }^{90}$ Cement industries were also responsible for negative effects on aquatic life and water resources..$^{90}$ The water quality of the Dhaleshwari River is deteriorating to a significant amount, and a major degradation in environmental quality might occur in a few years, posing a serious hazard to human and aquatic life. ${ }^{91}$ Proper steps need to be taken to save aquatic ecology. Conduction of EIA, Government support for technologies and facilities, wastewater treatment facilities and discharge treatment facilities need to be ensured..$^{70}$ Research activities, pretreatment facilities, laws and regulation, awareness program, technological development regarding environment need to be enforced..$^{71}$ Waste water treatment and regulation, awareness regarding pollution and protection strategies need to be taken. ${ }^{72}$ ETP installation. ${ }^{73,81,88}$ Regulated monitoring of heavy metalloids discharge ${ }^{69,76}$ to preserve water 
quality and effluent Management need to be ensured.69 Priority on polluted water treatment, policy implementation, management strategies and awareness need to be raised. ${ }^{78}$ LCA should be done for reducing environmental pollution. ${ }^{81}$ Treatment plants need to be adopted to maintain water quality. ${ }^{84}$ Monitoring coastal area along with further studies on industrial impact to coastal water need to be executed. ${ }^{85}$ Appropriate management of river with further investigation need to be ensured. ${ }^{88}$ Proper management and precautions regarding water contamination for betterment of aquatic habitation. ${ }^{88}$ River management and rehabilitation along with proper strategies, rules and regulation should be executed. 89

\section{Disruption of Forest Ecology}

Environmental pollution is exacerbated by industrial waste, which has a detrimental effect on the forest ecosystem. Commercial discharges have been reported as one of the leading causes of forest disruption and responsible for biological and environmental consequences such as biodiversity destruction, animal and plant extinction, and habitat depletion. ${ }^{92}$ The tanning, wood, and fertilizer industries' effluents all had an adverse effect on forest resources. ${ }^{90}$ The shrimp farming industry may have a detrimental effect on the ecology of mangrove forests, and heavy pollution may alter the biogeochemistry of such areas. ${ }^{93}$ Heavy metals have affected the Sundarban mangrove forest and environment, with high concentrations of metalloids ( $\mathrm{Fe}, \mathrm{Zn}$ and $\mathrm{Pb}$ ) contained in macrobenthos, with $\mathrm{Pb}$ concentrations exceeding the WHO's recommended limit. ${ }^{94}$ Still, significant concentrations of $\mathrm{Cd}$ and Fe were found in mudskippers and gastropods, implying that such metals were deposited in benthic fauna. ${ }^{94}$ Meanwhile, the Sundarban mangrove forest's ecology and biodiversity was reported as endangered, with industrial pollution identified as a significant contributor. ${ }^{95}$ The trace elements $\mathrm{Fe}$, $\mathrm{Cd}$, and $\mathrm{Cr}$ were found in higher concentrations in Sundarban sediments where Cd levels were moderate to severe. ${ }^{96}$ High concentration of $\mathrm{Cu}, \mathrm{Cr}, \mathrm{Ni}$, and $\mathrm{As}$ in the atmosphere have an eco-toxicological effect on living organisms. ${ }^{96}$ Contaminants such as heavy metals, physiochemical properties, polycyclic aromatic hydrocarbons (PAHs), polychlorinated biphenyl compounds (PCBs), organotin, oil, grease, asbestos had a detrimental impact on forest resources due to shipbreaking industries. ${ }^{74}$ Sustainable Management Plans, science studies, and conservation procedures must all be applied to conserve the forest. ${ }^{93}$ Ecological restoration, legal action, awareness, monitoring, and management actions should be implemented..$^{95}$ In case of ship-breaking industries, Government policies, supervision, monitoring, scientific research methodology, separate locations must be executed..$^{74}$

\section{Conclusion}

From the literature survey, it is evident that natural resources are being substantially affected by Industrial waste that responsible for pollution of air, water, and soil along with disruption of aquatic and forest ecology. Air quality is deteriorated due to the release of residual, solid waste, gaseous emissions, and particulate matter from industry. Heavy metal contamination has a substantial effect on water bodies, changing water properties and lowering water quality. Heavy metalloids, solid wastes, and metallic content pollute soil properties, leading to a substantial reduction in soil quality. Industrial pollutants are responsible for aquatic eutrophication and acidification, disruption in the growth development process, microbial contamination, deteriorated water quality, disturbed marine ecology, and aquatic biodiversity. Industrial waste has a toxicological impact on organisms, destroys forest ecology, and changes the biochemistry of forest areas. Industrialization is necessary for a country's development and stability, but it must be achieved in an environmentally responsible way. Initiatives to make sure that industrialization is sustainable, both in terms of mitigating environmental damage and promoting more environmentally responsible industries, are desperately needed.

\section{Acknowledgement}

Authors performed the study own their own without any external support or help.

\section{Funding}

The authors received no financial support for the research, authorship, and publication of this article. Acknowledgement: Authors performed the study own their own without any external support or help.

\section{Conflict of interest}

The authors declare no conflict of interest. 


\section{References}

1. kamruzzman. Location of Industries in Bangladesh. GeoDASH. Published August 29, 2016. http://geodash.gov.bd/layers/ geonode:location_of_industries_in_ bangladesh

2. Bbs. Statistical Year Book Of Bangladesh 2019. Statistics \& Informatics Division (Sid), Ministry Of Planning, Government Of The People's Republic Of Bangladesh; 2019.

3. World Bank. Employment in industry (\% of total employment) (modeled ILO estimate) - Bangladesh | Data. Published 2021. Accessed April 23, 2021. https://data. worldbank.org/indicator/SL.IND.EMPL. ZS?locations $=\mathrm{BD}$

4. Bbs. National Accounts Statistics. National Accounting Wing (Gdp And Foreign Trade), Statistics \& Informatics Division (Sid), Ministry Of Planning, Government Of The People's Republic Of Bangladesh.

5. Khan S. Curbing shrinkage of arable land. The Financial Express. https://thefinancialexpress. com.bd/views/curbing-shrinkage-of-arableland-1577549364. Published December 28, 2019.

6. Zakir HM, Islam MM, Hossain MS. Impact of urbanization and industrialization on irrigation water quality of a canal-a case study of Tongi canal, Bangladesh. Adv Environ Res. 2016;5(2):109-123.

7. World Bank. Agriculture, forestry, and fishing, value added (\% of GDP) - Bangladesh | Data. Published 2019. Accessed April 23, 2021. https://data.worldbank.org/indicator/NV.AGR. TOTL.ZS?locations=BD

8. World Bank. Clean and Resilient Growth in Bangladesh. The World Bank. Published 2018. https://www.worldbank.org/en/news/ feature/2018/09/16/clean-and-resilientgrowth-in-bangladesh

9. IQAIR. Bangladesh Air Quality Index (AQI) and Air Pollution information | AirVisual. Published April 23, 2021. Accessed April 23, 2021. https://www.iqair.com/us/bangladesh

10. Hasnat A, Rahman I, Pasha M. Assessment of environmental impact for tannery industries in Bangladesh. International Journal of
Environmental Science and Development. 2013;4(2):217.

11. Ghose B. Fisheries and aquaculture in Bangladesh: Challenges and opportunities. Annals of Aquaculture and Research. 2014;1(1):1-5.

12. Rasul MG, Faisal I, Khan MMK. Environmental pollution generated from process industries in Bangladesh. International journal of environment and pollution. 2006;28(1-2): 144-161.

13. Mia R, Selim M, Shamim A, Chowdhury M, Sultana S. Review on various types of pollution problem in textile dyeing \& printing industries of Bangladesh and recommandation for mitigation. Journal of Textile Engineering \& Fashion Technology. 2019;5(4):220-226.

14. Ahmed T, Chowdhury ZUM. Environmental burden of tanneries in Bangladesh. In: 36 Th Annual Conference of the International Association for Impact Assessment. ; 2016.

15. Juel MAI, Chowdhury ZUM, Mizan A, Alam MS. Toxicity and environmental impact assessment of heavy metals contaminated soil of Hazaribagh tannery area. In: Proceedings of $3^{\text {rd }}$ International Conference on Advances in Civil Engineering, CUET, Chittagong, Bangladesh. ; 2016:94-99.

16. Green DWJG. Consultant Report: Bangladesh: Managing Hazardous Waste. Asian Development Bank; 2010. https:// www.adb.org/sites/default/files/projectdocument/62157/38401-01-reg-tacr-02.pdf

17. Azom MR, Mahmud K, Yahya SM, Sontu A, Himon SB. Environmental impact assessment of tanneries: a case study of Hazaribag in Bangladesh. International Journal of Environmental Science and Development. 2012;3(2):152.

18. Pasha M, Hasan MA, Rahman I, Hasnat A. Assessment of ship breaking and recycling industries in Bangladesh-An effective step towards the achievement of environmental sustainability. In: International Conference on Agricultural, Environmental and Biologica. ; 2012. 
19. Islam MM, Mahmud K, Faruk O, Billah MS Textile dyeing industries in Bangladesh for sustainable development. International Journal of Environmental Science and Development. 2011;2(6):428.

20. Muhibbullah M, Molla MH, Ali KMB, Sarwar MI, Hossain N. Health hazards and risks of ship breaking activities in Bangladesh: An environmental impact assessment approach. European Journal of Advanced Research in Biological and Life Sciences. 2014;2(1):1-15.

21. Belal AR, Khan NA, Alam SA. Industrial pollution and the environment in Bangladesh: an overview. Asian Journal of Environmental Management. 1998;6(2):115-124.

22. Mahmood SAI. Air pollution kills 15,000 Bangladeshis each year: the role of public administration and governments integrity. Journal of Public Administration and Policy Research. 2011;3(5):129-140.

23. Begum BA, Hopke PK, Markwitz A. Air pollution by fine particulate matter in Bangladesh. Atmospheric Pollution Research. 2013;4(1):75-86.

24. Air Pollution Reduction Strategy for Bangladesh. :94.

25. Alam GJ. Environmental pollution of Bangladesh-it's effect and control. Pulp and Paper. 2009;51(13.17).

26. Rahman MM, Mahamud S, Thurston GD. Recent spatial gradients and time trends in Dhaka, Bangladesh, air pollution and their human health implications. Journal of the Air \& Waste Management Association. 2019;69(4):478-501.

27. Islam MM, Kashif Mahmud OF, Billah S. Assessment of Environmetal Impacts for Textile Dyeing Industries in Bangladesh.

28. Tasnuva A, Islam A, Azad AK. Impact of air pollutant on human health in kushtia sugar mill, bangladesh. International Journal of Scientific Research in Environmental Sciences. 2014;2(5):184.

29. Begum BA, Biswas SK, Hopke PK. Key issues in controlling air pollutants in Dhaka, Bangladesh. Atmospheric Environment. 2011;45(40):7705-7713.

30. Ahmed S, Hossain I. Applicability of air pollution modeling in a cluster of brickfields in Bangladesh. Chemical Engineering Research Bulletin. 2008;12:28-34.
31. Guttikunda SK, Begum BA, Wadud Z. Particulate pollution from brick kiln clusters in the Greater Dhaka region, Bangladesh. Air Quality, Atmosphere \& Health. 2013;6(2):357365.

32. Alom MM. Effects on environment and health by Garments factory waste in Narayanganj City, Dhaka. American Journal of Civil Engineering. 2016;4(3):64-67.

33. Islam MS, Mostafa MG. Environmental Hazards of Petroleum Refinery in Bangladesh: A Review. Petro Chem Indus Intern, 4 (1): 15. 2021;21:1-4.

34. Ahmed MJ, Ali MK, Hossain M, Siraj S, Ahsan MA. Determination of trace metals in air of Chittagong city-Bangladesh. European Journal of Chemistry. 2012;3(4):416-420.

35. Rahman MA, Bakri DA. A study on selected water quality parameters along the River Buriganga, Bangladesh. Iranica Journal of Energy \& Environment. 2010;1(2):81-92.

36. The United Nations World Water Development Report 4: Managing Water under Uncertainty and Risk, 2012.

37. Afrad MSI, Monir MB, Haque ME, Barau AA, Haque MM. Impact of industrial effluent on water, soil and Rice production in Bangladesh: a case of Turag River Bank. Journal of Environmental Health Science and Engineering. 2020;18(2):825-834.

38. Ahmed MS, Biswas MMH, Mottalib MA, Alam MN, Khan M. Translocation of heavy metals from industry into vegetables and crops through water and soil of Mokesh Beel in Bangladesh and their impact on human body. IOSR J Environ Sci Toxicol Food Technol. 2019;13:59-71.

39. Ahmad JU, Goni MA. Heavy metal contamination in water, soil, and vegetables of the industrial areas in Dhaka, Bangladesh. Environmental monitoring and assessment. 2010;166(1):347-357.

40. Roy S, Banna LN, Hossain M, Rahman H. Water quality of Narai canal and Balu river of Dhaka City: An impact of industrialization. Journal of the Bangladesh Agricultural University. 2014;12(2):285-290.

41. Zakir HM, Rahman MM, Rahman A, Ahmed I, Hossain MA. Heavy metals and major ionic pollution assessment in waters of midstream of the river Karatoa in Bangladesh. Journal 
of Environmental Science and Natural Resources. 2012;5(2):149-160.

42. Hasan MK, Shahriar A, Jim KU. Water pollution in Bangladesh and its impact on public health. Heliyon. 2019;5(8):e02145.

43. Zahir $\mathrm{H}$, Ahmeduzzaman M. A case study on the impact of the leather industries on the ground water aquifer in Bangladesh. International Journal of Civil and Environmental Engineering. 2012;12(5).

44. Ahsan MA, Satter F, Siddique MAB, et al. Chemical and physicochemical characterization of effluents from the tanning and textile industries in Bangladesh with multivariate statistical approach. Environmental monitoring and assessment. 2019;191(9):1-24.

45. Islam MM, Mahmud K, Faruk O, Billah S. Assessment of environmental impacts for textile dyeing industries in Bangladesh. In: International Conference on Green Technology and Environmental Conservation (GTEC-2011). IEEE; 2011:173-181.

46. Hossain L, Sarker SK, Khan MS. Evaluation of present and future wastewater impacts of textile dyeing industries in Bangladesh. Environmental Development. 2018;26:23-33.

47. Hossain MA, Hossain MI. The Environmental Impacts of Textile Dyeing Industries in Bangladesh. Research Journal of Advanced Engineering and Science. 2020;5(2):113-116.

48. Hossain A, Nakamichi S, Habibullah-AlMamun M, Tani K, Masunaga S, Matsuda $\mathrm{H}$. Occurrence and ecological risk of pharmaceuticals in river surface water of Bangladesh. Environmental research. 2018;165:258-266.

49. Quasem MA. Conversion of agricultural land to non-agricultural uses in Bangladesh: extent and determinants. The Bangladesh Development Studies. Published online 2011:59-85.

50. Hossain MA, Huggins R. The Environmental and Social Impacts of Unplanned and Rapid Industrialization in Suburban Areas: The Case of the Greater Dhaka Region, Bangladesh. Environment and Urbanization ASIA. 2021;12(1):73-89.

51. Rezvi MR. The Factors of Declining Agricultural Growth in Bangladesh and Its Impact on Food Security. South Asian Journal of Social Studies and Economics. Published online 2018:1-9.

52. Islam MM, Karim M, Zheng X, Li X. Heavy metal and metalloid pollution of soil, water and foods in bangladesh: a critical review. International journal of environmental research and public health. 2018;15(12):2825.

53. Alam SS, Osman KT, Kibria MG. Heavy metal pollution of soil from industrial and municipal wastes in Chittagong, Bangladesh. Archives of Agronomy and Soil Science. 2012;58(12):1427-1438.

54. Abedin MA, Jahiruddin M. Waste generation and management in Bangladesh: An overview. Asian Journal of Medical and Biological Research. 2015;1(1):114-120.

55. Rahman $\mathrm{SH}$, Khanam D, Adyel TM, Islam MS, Ahsan MA, Akbor MA. Assessment of heavy metal contamination of agricultural soil around Dhaka Export Processing Zone (DEPZ), Bangladesh: implication of seasonal variation and indices. Applied sciences. 2012;2(3):584-601.

56. Proshad R, Kormoker T, Mursheed N, et al. Heavy metal toxicity in agricultural soil due to rapid industrialization in Bangladesh: a review. International Journal of Advanced Geosciences. 2018;6(1):83-88.

57. Islam F, Zakir HM, Rahman A, Sharmin S. Impact of Industrial Wastewater Irrigation on Heavy Metal Deposition in Farm Soils of Bhaluka Area, Bangladesh. J Geog Environ Earth Sci Int. 2020;24(3):19-31.

58. Islam SM, Tusher TR, Mustafa M, Mamun SA. Investigation of soil quality and heavy metal concentrations from a waste dumping site of Konabari industrial area at Gazipur in Bangladesh. IOSR J Environ Sci Toxicol Food Technol. 2012;2(1):1-7.

59. Mondol MN, Chamon AS, Faiz B, Elahi SF. Seasonal variation of heavy metal concentrations in Water and plant samples around Tejgaon industrial Area of Bangladesh. Journal of Bangladesh academy of sciences. 2011;35(1):19-41.

60. Rahman MM, Howladar MF, Faruque MO. Assessment of soil quality for agricultural purposes around the Barapukuria coal mining industrial area, Bangladesh: insights from chemical and multivariate statistical analysis. Environmental Systems Research. 
2017;6(1):1-13.

61. Kormoker T, Proshad R, Islam S, et al. Toxic metals in agricultural soils near the industrial areas of Bangladesh: ecological and human health risk assessment. Toxin reviews. Published online 2019:1-20.

62. Proshad R, Kormoker T, Islam MS, Chandra $\mathrm{K}$. Potential health risk of heavy metals via consumption of rice and vegetables grown in the industrial areas of Bangladesh. Human and ecological risk assessment: an international journal. Published online 2019.

63. Ahmed M, Matsumoto M, Kurosawa K. Heavy metal contamination of irrigation water, soil, and vegetables in a multiindustry district of Bangladesh. International Journal of Environmental Research. 2018;12(4):531-542.

64. Al Zabir A, Zzaman MW, Hossen MZ, Uddin MN, Islam MS, Islam MS. Spatial dissemination of some heavy metals in soil adjacent to Bhaluka industrial area, Mymensingh, Bangladesh. American Journal of Applied Scientific Research. 2016;2(6):3847.

65. Aktaruzzaman M, Fakhruddin AN, Chowdhury MA, Fardous Z, Alam MK. Accumulation of heavy metals in soil and their transfer to leafy vegetables in the region of Dhaka Aricha Highway, Savar, Bangladesh. Pakistan journal of biological sciences: PJBS. 2013;16(7):332338.

66. Islam S, Ahmed K, Masunaga S. Potential ecological risk of hazardous elements in different land-use urban soils of Bangladesh. Science of the Total Environment. 2015;512:94-102.

67. Azom MR, Mahmud K, Yahya SM, Sontu A, Himon SB. Environmental impact assessment of tanneries: a case study of Hazaribag in Bangladesh. International Journal of Environmental Science and Development. 2012;3(2):152.

68. Bhuyan MS, Islam MS. A critical review of heavy metal pollution and its effects in Bangladesh. Science Journal of Energy Engineering. 2017;5(4):95.

69. Ali MM, Ali ML, Islam MS, Rahman MZ. Preliminary assessment of heavy metals in water and sediment of Karnaphuli River, Bangladesh. Environmental Nanotechnology,
Monitoring \& Management. 2016;5:27-35.

70. Hossain MS. Biological aspects of the coastal and marine environment of Bangladesh. Ocean \& Coastal Management. 2001;44(3-4):261-282.

71. Salequzzaman M, Islam ST, Tasnuva A, Kashem MA, Masud MMA. Environmental impact of sugar industry a case study on Kushtia sugar mills in Bangladesh. J Innov Dev Strat. 2008;2(3):31.

72. Khan AS, Hakim A, Rahman M, Mandal $\mathrm{BH}$, Ahammed $\mathrm{F}$. Seasonal water quality monitoring of the Bhairab River at Noapara industrial area in Bangladesh. SN Applied Sciences. 2019;1(6):1-8.

73. Dey S, Islam A. A review on textile wastewater characterization in Bangladesh. Resour Environ. 2012;5(1):15-44.

74. Hossain MS, Fakhruddin ANM, Chowdhury MAZ, Gan SH. Impact of ship-breaking activities on the coastal environment of Bangladesh and a management system for its sustainability. Environmental Science \& Policy. 2016;60:84-94.

75. Abdullah HM, Mahboob MG, Banu MR, Seker DZ. Monitoring the drastic growth of ship breaking yards in Sitakunda: a threat to the coastal environment of Bangladesh. Environmental monitoring and assessment. 2013;185(5):3839-3851.

76. Kibria G, Hossain MM, Mallick D, Lau TC, Wu $\mathrm{R}$. Trace/heavy metal pollution monitoring in estuary and coastal area of Bay of Bengal, Bangladesh and implicated impacts. Marine pollution bulletin. 2016;105(1):393-402.

77. Proshad R, Islam S, Tusher TR, et al. Appraisal of heavy metal toxicity in surface water with human health risk by a novel approach: a study on an urban river in vicinity to industrial areas of Bangladesh. Toxin Reviews. Published online 2020:1-17.

78. Mahbub A, Tanvir HM, Afrin LT. An evaluation of environmental and social impact due to industrial activities-A case study of Bangshi river around Dhaka Export Processing Zone (DEPZ), Bangladesh. Int Res J Environ Sci. 2014;3(2):103-111.

79. Sarker BC, Baten MA, Eqram M, et al. Heavy metals concentration in textile and garments industries' wastewater of Bhaluka industrial area, Mymensingh, Bangladesh. Current 
World Environment. 2015;10(1):61.

80. Akter M, Sikder T, Ullah A. Water quality assessment of an industrial zone polluted aquatic body in Dhaka, Bangladesh. American Journal of Environmental Protection. 2014;3(5):232-237.

81. Chowdhury ZUM, Ahmed T, Antunes APM, Paul HL. Environmental life cycle assessment of leather processing industry: A case study of Bangladesh. J Soc Leather Technol Chem. 2018;102:18-26.

82. Islam S, Islam S, Islam SA, Eaton DW. Total and dissolved metals in the industrial wastewater: A case study from Dhaka metropolitan, Bangladesh. Environmental Nanotechnology, Monitoring \& Management. 2016;5:74-80.

83. Bhuyan MS, Islam MS. Status and impacts of industrial pollution on the karnafully river in Bangladesh: a review. International Journal of Marine Science. 2017;7.

84. Das M, Ahmed MK, Islam MS, Islam MM, Akter MS. Heavy metals in industrial effluents (Tannery and Textile) and adjacent rivers of Dhaka city, Bangladesh. Terrestrial and Aquatic Environmental Toxicology. 2011;5(1):8-13.

85. Islam MS, Mohanta SC, Siddique MAB, Abdullah-Al-Mamun M, Hossain N, Bithi $\mathrm{UH}$. Physico-chemical assessment of water quality parameters in Rupsha river of Khulna region, Bangladesh. The international journal of engineering and science (ijes). 2018;7:73-78.

86. Hashem MA, Islam A, Mohsin S, Nur-ATomal MS. Green environment suffers by discharging of high-chromium-containing wastewater from the tanneries at Hazaribagh, Bangladesh. Sustainable Water Resources Management. 2015;1(4):343-347.

87. Rahman S. Aspects and impacts of ship recycling in Bangladesh. Procedia engineering. 2017;194:268-275.

88. Rashid H, Hasan MN, Tanu MB, et al. Heavy metal pollution and chemical profile of Khiru River, Bangladesh. Int J Environ. 2012;2:57-63.

89. Sultana MN, Hossain MS, Latifa GA. Water Quality Assessment Of Balu River, Dhaka Bangladesh. Water Conservation \& Management. 2019;3(2):08-10.

90. Hoque A, Mohiuddin M, Su Z. Effects of industrial operations on socio-environmental and public health degradation: evidence from a least developing country (LDC). Sustainability. 2018;10(11):3948.

91. Ghosh P, Hossain M. Assessment of Tannery Effluent: A Case Study on Dhaleshwari River in Bangladesh. In: Proceedings of International Conference on Planning, Architecture and Civil Engineering. Rajshahi University of Engineering \& Technology; 2019.

92. Iftekhar MS. Forestry in Bangladesh: an overview. Journal of Forestry. 2006;104(3):148-153.

93. Rahman MM, Rahman MM, Islam KS. The causes of deterioration of Sundarban mangrove forest ecosystem of Bangladesh: conservation and sustainable management issues. Aquaculture, Aquarium, Conservation \& Legislation. 2010;3(2):77-90.

94. Ahmed K, Mehedi Y, Haque R, Mondol P. Heavy metal concentrations in some macrobenthic fauna of the Sundarbans mangrove forest, south west coast of Bangladesh. Environmental monitoring and assessment. 2011;177(1):505-514.

95. Islam SD-U, Bhuiyan MAH. Sundarbans mangrove forest of Bangladesh: causes of degradation and sustainable management options. Environmental Sustainability. 2018;1(2):113-131.

96. Islam MA, Al-Mamun A, Hossain F, et al. Contamination and ecological risk assessment of trace elements in sediments of the rivers of Sundarban mangrove forest, Bangladesh. Marine pollution bulletin. 2017;124(1):356-366. 